\title{
O ATIVISMO JUDICIAL E A DEMOCRACIA DO PONTO DE VISTA DO INDIVÍDUO: A QUESTÃO DAS RELAÇÕES DE UNIÃO HOMOAFETIVA
}

\author{
JUDICIAL ACTIVISM AND DEMOCRACY FROM AN INDIVIDUAL \\ APPROACH: THE SAME-SEX UNIONS ISSUE
}

\section{Antonio Henrique Graciano Suxberger}

Professor do Programa de Mestrado e Doutorado em Direito do Centro Universitário de Brasília (UniCEUB). Professor do Máster Oficial em Direitos Humanos, Interculturalidade e Desenvolvimento da Universidade Pablo de Olavide (Sevilha, Espanha) e Universidade Internacional da Andaluzia. Professor da Fundação Escola Superior do MPDFT (FESMPDFT) e da Escola Superior do Ministério Público da União (ESMPU). Mestre e Doutor em Direito. Promotor de Justiça no Distrito Federal.

E-mail: antonio.suxberger@uniceub.br

\section{José Wilson Ferreira Lima}

Mestre em Direito pelo Instituto de Direito de Brasília - IDP e Doutorando em Direito pelo Centro Universitário de Brasília - UniCEUB. Promotor de Justiça no Distrito Federal.

E-mail: wferreiraster@gmail.com

Recebido em: 23/05/2017

Aprovado em: 08/02/2019

RESUMO: O artigo aborda a questão do ativismo judicial considerando-o como consequência da omissão do legislador, que não cumpriu os mandamentos constitucionais para a edição das leis necessárias ao regular exercício de direitos reputados essenciais. Sustenta que a Constituição favorece as práticas judiciais ativistas como forma de controlar a omissão legislativa inconstitucional. Assume-se que, para o indivíduo, a atuação judicial ativista é importante fator para a satisfação de seus direitos e dignidade, em razão da inércia insuperável do legislador.O reconhecimento judicial das uniões homoafetivas presta-se como exemplo de concretização de um direito constitucional assegurado ao indivíduo. Ainda assim, após o reconhecimento judicial do direito constitucionalmente assegurado, o legislador permanece autorizado a melhor conformar esse direito com observância dos parâmetros mínimos estabelecidos pelo Judiciário. Metodologicamente, o artigo se vale da revisão bibliográfica sobre o tema e da análise documental a partir de casos selecionados da jurisprudência do Supremo Tribunal Federal, especialmente colhidos a respeito da concretização de direitos fundamentais por meio do ativismo judicial.

Palavras-chave: Direitos Fundamentais. Controle de Constitucionalidade. Ativismo Judicial.Omissão Legislativa. Dignidade da Pessoa Humana. União homoafetiva.

ABSTRACT: The article analyses the judicial activism as a result of lack of legislature. Contrary to some mandatory demands of legislation, Brazilian legislature has been failing on stablishing the necessary ways to assure the fruition of constitutional rights. The paper assays the Brazilian Constitution aids activism practices as an instrument to blunt unconstitutional legislator's 
absence. It asserts that judicial activism performs an import factor to certify and ensure individual's rights and its own dignity undeterred by the legislator's omission. The judicial recognition of same-sex unions represents an example of assuring a constitutional right granted to an individual. Nevertheless, after the judicial recognition, the legislature is still allowed to acclimate a constitutional right observing the minimal parameters stablished by the Judiciary. Methodologically, the papers reviews the most important authors and collects cases from the Brazilian Supreme Court, especially on fundamental rights enacted by judicial decisions.

Keywords:Fundamental Rights.Judicial Review.Judicial Activism.Legislative Omission.Dignity of Human Person.Same-sex unions.

SUMÁRIO: Introdução; 1 A Busca pela Isonomia de Tratamento nas Relações deUnião Homoafetiva; 2Referenciais Normativos da União Estável; 3Considerações sobre o Ativismo Judicial;4 A Posição Contramajoritária do Supremo Tribunal Federal; 5 O Regime Democrático Favorece o Ativismo Judicial; 6 Inatividade e Omissão do Poder Legislativo; 7 O Indivíduo entre o Ativismo Judicial e o Inativismo Legislativo; Conclusão; Referências.

\section{INTRODUÇÃO}

A lei da natureza mais conhecidaé a da ação e reação, segundo a qual para cada efeito há uma correspondente causa que o estabelece, mantendo-se entre estasforças a mesma medida quanto à intensidade, uma vez que são grandezas diretamente proporcionais.

Paralelamente a isso, a relação de causa e efeito pode ser verificada em muitos aspectosda dinâmica da ordem social, citando-se como exemplo a relação existente entre a produção da norma jurídica (efeito) e os fatos sociais mais relevantes que a antecederam (causa). Nesse cenário, o Direito, objetivamente considerado, deveria corresponder às expectativas gerais da sociedade, de modo a tornar mais harmoniosasas possíveis relações fáticas.Com efeito, devese atenção à circunstância de que por vezes as forças resultantes dessasrelações funcionam como a ação (causa) que provoca ou busca algum resultado, procurando encontrar no Direito a correspondente resposta (efeito). Mas a verdade é que nem sempre o Direito consegue acompanhar a evolução social em sua dinâmica plena, ainda mais se o legislador não laborar de modo a satisfazer as aspirações sociais mais essenciais, omitindo-se no cumprimento de algumas importantes determinações constitucionais.

É na ordem política, especialmente fundadana democracia representativa, como a que caracteriza o Estado brasileiro, que se definiua competência do Poder Legislativopara dispor quanto às normas gerais e especiais que comporão o ordenamento jurídico-normativo e garantirão que cada indivíduo usufrua concretamente de seus direitos, a partir das expectativas identificadas.Em regra, essas normas são produzidas como respostas às ações da sociedade,que pretende obter a confirmação ou a regulação de algum direito ou mesmo o estabelecimento de novos direitos,acriação, a modificaçãoou, conforme o caso, a vedação da prática de comportamentos que se possa considerar antissociaisou prejudiciais aos interesses da maioria. Nesse aspecto, o Direito objetivo deveria corresponder a essas expectativas sociais e individuais, de modo a torná-las mais harmoniosas e justas.

Segundo a teoria política, a atividade legislativa, via constitucionalmente definida para o exercício dessa competência, legitima-se a partir do exercício do voto popular, por intermédio do qual cada indivíduo delega poderes a seus representantes, com o propósito de que estes garantam a funcionalidade do Poder Legislativo e a consequente criação, modificação ou extinção das leis, permitindo-se, com isso, o pleno exercício dos direitos estabelecidos, sempre de forma adequada e oportuna, atendendo-se às antigas e, principalmente, às atuais aspirações sociais e individuais. 
Deve-se considerar, nesse contexto, que a sociedade está em constante mutação, de modo que há valores e conceitos sofrendo contínuas mudanças, o que exigeos necessários ajustes, de tempos em tempos.

Apesar disso, o exercício do mandato conferido aos legisladores (representantes), mediante o voto de cada cidadão (representados), na forma democraticamente estabelecida, nem sempre corresponde e atende às expectativas, especialmente nos casos em que o Poder Legislativo deixa de produzir as normas necessárias para a efetivação dos direitos segundo as demandas sociais manifestadas, o que, além de evidenciar a omissão na prestação da atividade legislativa, revela, de certo modo, a falta de compromisso dos representantes para com os seus representados, nesse caso o povo, único e legítimo detentor do Poder. Mas essa omissão também revela certo grau de despreparo e de inabilidade política para o conhecimento das demandas e a composição do cenário favorável em busca de ao menos estabelecer produtivos debates em torno do conhecimento e da solução destas, tudo de forma a superar eventuais entraves e entregar aos titulares do Poder as leis que lhes oportunizem a fruição regular de seus direitos.

Mas, ante a inércia legislativa, as demandas sociais mais sérias e importantes tornaramse mais intensas e repetitivas, de modo que as possíveis soluções passaram a ser exigidas e, em alguns casos, definidas fora do âmbito da competência legislativa. Nesse cenário, o Poder Judiciário tem sido acionado por intermédio das medidas constitucionais e legais disponíveis e, em face da própria indeclinabilidade da Jurisdição, as soluções para inúmeros conflitos e anseios sociais deixaram de ser definidos na esfera legislativa, como ordinariamente deveria ocorrer, quando a solução das demandas dependerem de regulação normativa, mediante a produção de leis, passando a se submeter ao crivo e ao inafastável controle judicial.

Em razão dessa realidade, constituída especialmente em decorrência de reiteradas omissões do Poder Legislativo, a postura mais ativa do Poder Judiciário se afirmou como consequência da provocação do jurisdicionado insatisfeito, tornou-se mais frequente e, porvezes, ingressouna seara de direitos sensíveisjá estabilizados, mas que, com o passar do tempo, passaram a exigir novas abordagens, inclusive de forma contrária às tradições supostamente tidas como insuperáveis.Exemplo disso são as antigas concepções e tradições, talvez mais religiosas e morais do que propriamente jurídicas, quanto à indissolubilidade do casamento, uma vez que mais recentemente o Estado brasileiro formalmente passou a admitir o divórcio, inaugurando com esse instituto nova fase, já tardiamente adotada em superação à vetusta instituição do desquite.

Em verdade, o Poder Judiciário moderno assumiu o papel de protagonista de decisões bastante inovadoras ${ }^{1}$ e que podem atingir não apenas o interesse individual discutido em processo inter partes, alcançando mais profundamente a sociedade em sua dimensão total. Nesse aspecto, a decisão judicial com eficácia geral (erga omnes) e efeito vinculante, adotada em processo manejado em face de reconhecida inconstitucionalidade, assume a semelhança de lei, não se podendo ignorar que, além disso, o indivíduo é tanto credor da prestação legislativa (tutela geral e abstrata), que estabelece e fixa seus direitos, quando é credor da prestação judicial (tutela específica e concreta), inclusive a decorrente da própria omissão legislativa.

Desse modo, surgindo demandas judiciais em torno de direitos constitucionais tutelados,mas não regulamentados na esfera legislativa, e havendo a consequente provocação para o suprimento desse hiato legislativo, reclamando a intervenção do Poder Judiciário, abre-se a oportunidade para a produção de decisões inovadoras e às vezes polêmicas, em substituição à atividade legiferante, ao que se convencionou denominar de ativismo judicial. Consequentemente, pode-se dizer que oativismo judicial (efeito) é forma de reação ao inativismo legislativo (causa) e, com isso, identifica-se que os segmentos sociais e estatais reproduzem, internamente, a lei natural de ação e reação.

${ }^{1}$ Decisões de caráter não apenas jurídico, mas também político.

Revista de Direito Brasileira | Florianópolis, SC | v. 23 | n. 9 | p. 172-196 |Mai./Ago. 2019 
Neste artigo, pretende-se abordar a temática do ativismo judicial (efeito) no contexto da realidade fática e jurídica que o envolve e nos limites da ordem democrática, concebendo-o como acontecimento decorrente do inativismo legislativo (causa).O objetivo do estudo cinge-se em demonstrar que os sistemas social e político mantêm-se em constante atividade, buscando soluções para os mais diversos problemas da sociedade, certo de que há casos em que essas soluções nãotransgridem o regime democrático, mas antes o confirmam.

Em razão disso, o problema que orientará o desenvolvimento do estudo consistirá em determinar em que medida a relação entre o ativismo judicial e o inativismo legislativo não ofende a ordem democrática, especificamente quanto à eventual sobreposição de um Poder ao outro.

Para dar curso ao estudo, a abordagem focalizará a concretização do Direito como proposta final de atendimento da dignidade humana, identificando a posição do indivíduo frente a essa realidade, anacrônica e paradoxal, na qual o Poder legitimado se omite (Legislativo), enquanto outro Poder, teoricamente não legitimado (Judiciário), avança, decide e supre a omissão.

A omissão legislativa, como se verá a seguir, nos temas constitucionalmente estabelecidos, não se confunde com uma pretensa inércia política. Se processos de luta culminaram na positivação de direitos na Carta Constitucional, isso não se traduz automaticamente no consenso político para o minudenciamento das garantias necessárias à fruição desses direitos. Daí a relevância do ativismo judicial, legitimamente estabelecido para a concretização de direitos expressa ou argumentativamente positivados no marco constitucional.

Para conferir maior grau de objetividade, impõe-se fazer um recorte estratégico quanto à adoção da premissa de que tanto o Poder Legislativo quanto o Poder Judiciário encontram-se igualmente aparelhados e dotados dos recursos necessários para a realização concreta de suas competências constitucionais, não se admitindo, portanto, escusas no sentido de que um Poder ou outro deixou de concretizar suas competências em razão da carência de recursos.

O artigo se vale de revisão bibliográfica especialmente dos autores que cuidam da presença de direitos e garantias fundamentais extraídos da Constituição por meio da intermediação legislativa ou por meio da intervenção jurisdicional. Cuida, igualmente, de análise documental, com destaque ao caso eleito, qual seja, a união homoafetiva e a necessária complementação normativa para a fruição dos direitos decorrentes do reconhecimento da unidade familiar na Constituição Federal.

Por último, registre-se que o desenvolvimento deste estudo se orientará em torno de um caso concreto, que servirá de ilustração da vertente empírica, quanto à atuação do Poder de Judiciário, produzindo decisão ativista em decorrência da falta legislativa, consistente em nãoenfrentara questão e propor as medidas legais reclamadas. Esse referencial é o caso discutido e resolvido na Ação Direta de Inconstitucionalidade (ADI) n. 4.277/DF, que dispôs sobre os direitos dos parceirosna união homoafetiva.

\section{A bUSCA PELA ISONOMIA DE TRATAMENTO NAS RELAÇÕES DE UNIÃo HOMOAFETIVA}

Este tópico se presta essencialmente para descrever a decisão adotada pelo Supremo Tribunal Federal (STF), em sede de controle de constitucionalidade, quanto a um interesse social muitíssimo importante, que atinge parcela significativa da população brasileira, havendo ainda de produzir reflexos no cenário internacional, especialmente nos países que, tal como o Brasil, carecem de legislação especifica que disponha sobre a união de pessoas de mesmo sexo.

Trata-se da regulamentação dos direitos e dos deveres decorrentes da união homoafetiva, em relação aos quaisse pretende que os conflitos existentessejam resolvidos com os 
mesmoscritérios aplicáveis à união heteroafetiva.Nesse contexto, talvez o primeiro e mais importante passo seja o de afastar o preconceito que envolve esse tipo de relação:

Por absoluto preconceito, a Constituição emprestou, de modo expresso, juridicidade somente às uniões estáveis entre um homem e uma mulher, ainda que em nada se diferencie a convivência homossexual da união estável heterossexual. A nenhuma espécie de vínculo que tenha por base o afeto pode-se deixar de conferir status de família, merecedora da proteção do Estado, pois a Constituição $\left(1^{\circ}\right.$, III) consagra, em norma pétrea, o respeito à dignidade da pessoa humana.

Necessário é encarar a realidade sem discriminação, pois a homoafetividade não é uma doença nem uma opção livre. Assim, descabe estigmatizar a orientação homossexual de alguém, já que negar a realidade não soluciona as questões que emergem quando do rompimento dessas uniões. Não há como chancelar o enriquecimento injustificado e deferir, por exemplo, no caso de morte do parceiro, a herança aos familiares, em detrimento de quem dedicou a vida ao companheiro, ajudou a amealhar patrimônio e se vê sozinho e sem nada (DIAS, 2013, p. 46).

Inicialmente, a ação de controle concentrado, autuada comoADI n. 4.277/DF no STF ${ }^{2}$, teve como objeto dar "interpretação conformea Constituição" ao art. 1.723 do Código Civil, que regulamenta a união estável heteroafetiva: "É reconhecida como entidade familiar a união estável entre o homem e a mulher, configurada na convivência pública, contínua e duradoura e estabelecida com o objetivo de constituição de família" (BRASIL, 2002).O objeto da ADI n. 4.277/DF resumiu-se na pretensão de tratamento jurídico isonômico a ser conferido às relações conjugais sob a forma de união homoafetiva, que se caracterizem pelos atributos da durabilidade, da publicidade e da continuidade, além do propósito claro de constituição de família, o que exige se atribuaa essas relações o reconhecimento jurídico idêntico ao que é legalmente dispensado às relações conjugais heteroafetivas (BRASIL, 2011b, p. 626-629).

A par disso, destaca-se, quanto ao julgamento da ADI em exame, entre outros importantes fundamentos, que o "sexo das pessoas, salvo disposição constitucional expressa ou implícita em sentido contrário, não se presta como fator de desigualação jurídica" e o "reconhecimento do direito à preferência sexual como direta emanação da dignidade da pessoa humana" (BRASIL, 2011b, p. 612).

Nesse julgamento, ainda foi levado em conta que a atual Constituição Federal (CF) não empregou a expressão "família" no sentido limitado de que sua composição ocorra apenaspelos vínculos de casais heteroafetivos e que a sua formalização se reduza ao campo estreito do ambiente cartorário e das celebrações religiosas, atentando-se que a CF avançou no plano dos costumes e incorporou o regime do pluralismo sócio-político-cultural (BRASIL, 2011b, p. 613).Além disso, a CF não vedou a formação das famílias por pessoas de mesmo sexo e, nesse contexto, inexiste o direito de os indivíduos heteroafetivos invocarem a sua não-equiparação jurídica com os indivíduos homoafetivos (BRASIL, 2011b, p. 614).

Em consequência, o STF reconheceu a união de parceiros de mesmo sexo como nova categoria de entidade familiar e, nesse sentido, deu ao art. 1.723 do Código Civil "interpretação conforme a Constituição", julgando procedente a ADI n. 4.277/DF, com eficácia erga omnes e efeito vinculante, e reconheceu aplicável em favor da união estável homoafetiva as mesmas regras e consequências jurídicas da união estável heteroafetiva (BRASIL, 2011b, p. 615).

\footnotetext{
${ }^{2}$ Conjuntamente com a ADI n. 4.277/DF, o STF julgou a ADPF n. 132/RJ, pela qual igualmente se pretendia conferir interpretação conforme à Constituição ao art. 1.723 do Código Civil. No caso, o STF recebeu e conheceu a ADPF em comento como Ação Direta de Inconstitucionalidade e, ao final, esta e a ADI n. 4.277/DF foram julgadas procedentes, com eficácia erga omnes e efeito vinculante.
}

Revista de Direito Brasileira | Florianópolis, SC | v. 23 | n. 9 | p. 172-196 |Mai./Ago. 2019 
Nesse aspecto, a técnica deinterpretação conforme:

Destina-se à preservação da validade de determinadas normas, suspeitas de inconstitucionalidade, assim como à atribuição de sentido às normas infraconstitucionais, da forma que melhor realizem os mandamentos constitucionais $[\ldots]$

Como técnica de interpretação, o princípio impõe a juízes e tribunais que interpretem a legislação ordinária de modo a realizar, da maneira mais adequada, os valores e fins constitucionais. Vale dizer: entre interpretações possíveis, devese escolher a que tem mais afinidade com a Constituição (BARROSO, 2015, p. 336).

Com essa decisão, o STF deu passos à frente do Poder Legislativo federal, assumindo postura ativa, uma vez que supriu a lacuna legislativa, diante de interesse nacionalmente reclamado, além de possibilitar a efetiva solução dos conflitos decorrentes das relações homoafetivas, que em nada divergem dos possíveis conflitos vivenciados pelos casais heteroafetivos.

A decisão sobre essa questão favorece, ainda, a construção de parâmetros para a solução de futuros casos dessa mesma natureza (precedentes), mesmo que o Poder Legislativo mantenhase inerte no enfrentamento dessa disciplina, deixando de regulamentá-la pela via legal-normativa. Com isso, é certo que nenhum indivíduo ficará à mercê e à espera da atuação de seus representantes no Parlamento para a produção da lei que deverá dispor sobre os direitos e deveres no âmbito das relações conjugais homoafetivas.

\section{REFERENCIAIS NORMATIVOS DA UNIÃO ESTÁVEL}

Um rápido exame da legislação produzida acerca da regulamentação da união estável, seguindo o critério cronológico, é suficiente para se concluir que em nenhum momento o legislador se ocupou em definir qualquer regramento, mínimo que fosse, sobre os direitos e os deveres decorrentes da união homoafetiva. Diante dessa realidade, tendo-se como primeira referência a CF, verifica-se que ela dispôs sobre a proteção do núcleo familiar (BRASIL, 2011a) e, algum tempo depois, deu-se o primeiro passo disciplinando-se as relações decorrentes da união estável (BRASIL, 1996). Finalmente, o novo Código Civil acolheu e dispôs sobre a união estável, reconhecendo-a como entidade familiar (BRASIL, 2002) e consolidou normativamente essa questão:

Tabela 1 - Legislação sobre a União Estável.

\begin{tabular}{|l|c|l|}
\hline \multicolumn{1}{|c|}{ LEGISLAÇÃO } & ANO & \multicolumn{1}{c|}{ NORMA } \\
\hline Constituição Federal & $\mathbf{1 9 8 8}$ & $\begin{array}{l}\text { Art. 226. A família, base da sociedade, tem especial proteção do Estado. } \\
\S 3^{\circ} \text { Para efeito da proteção do Estado, é reconhecida a união estável entre o } \\
\text { homem e a mulher como entidade familiar, devendo a lei facilitar sua } \\
\text { conversão em casamento. } \\
\S 4^{\circ} \text { Entende-se, também, como entidade familiar a comunidade formada por } \\
\text { qualquer dos pais e seus descendentes. }\end{array}$ \\
\hline Lei da União Estável & $\mathbf{1 9 9 6}$ & $\begin{array}{l}\text { Art. 1 É reconhecida como entidade familiar a convivência duradoura, } \\
\text { pública e contínua, de um homem e uma mulher, estabelecida com objetivo } \\
\text { de constituição de família. }\end{array}$ \\
\hline Código Civil & $\mathbf{2 0 0 2}$ & $\begin{array}{l}\text { Art. 1.723. É reconhecida com entidade familiar a união estável entre o } \\
\text { homem e a mulher, configurada na convivência pública, contínua e } \\
\text { duradoura e estabelecida com o objetivo de constituição de família. }\end{array}$ \\
\hline
\end{tabular}


Com a conjugação dessas normas, percebe-se que houve a predisposição de se ampliar a abrangência da família, não apenas em torno da visão tradicional, que seria aquela formada em decorrência do casamento, como também para admitir como entidade familiar o núcleo formado por uma comunidade de pessoas, envolvendo a figura dos genitores e de seus descendentes. Esse arranjo normativo, por certo, admite a extensão de seu alcance conceitual para abranger as relações de união estável entre casais homoafetivos, uma vez que a CF não apenas assegura a igualdade perante a lei, como também veda a privação de direitos motivada por convicções pessoais:

Art. $5^{\circ}$ Todos são iguais perante a lei, sem distinção de qualquer natureza, garantindo-se aos brasileiros e aos estrangeiros residentes no País a inviolabilidade do direito à vida, à liberdade, à igualdade, à segurança e à propriedade, nos termos seguintes:

VIII - ninguém será privado de direitos por motivo de crença religiosa ou de convicção filosófica ou política [...] (BRASIL, 2011a).

Nesse aspecto, não se pode negar que a união estável constitui espécie de entidade familiar, cuja formação gera direitos e deveres a seus integrantes, tais como aqueles decorrentes do casamento civil e, de igual modo, que a união estável entre pessoas de mesmo sexo constituise noutra espécie de entidade familiar, em relação à qual há a geração dos mesmos direitos e deveres para serem suportados mutuamente pelos integrantes dessa novasociedade conjugal de fato.Além disso, é relevante considerar que o STF assimilou esse novo modo de viver estabelecido factualmente pelas pessoas e pelas novas famílias e, consequentemente, ao resolver a ADI n. 4.277/DF, reconheceu válidos os vínculos pessoais e jurídicos decorrentes da união estável homoafetiva, especialmente em razão da omissão legislativa, que ainda persiste, e tornou efetivos os direitos tuteladospela nova ordem constitucional.

Posteriormente, mas ainda em consequência do entendimento firmado na mencionada ADI n. 4.277/DF, o Conselho Nacional de Justiça (CNJ) determinousua aplicação pelos ofícios de registro civil em todo o País, nos termos da Resolução n. 175/2013, dispondo que: "Art. $1^{\circ}$ É vedada às autoridades competentes a recusa de habilitação, celebração de casamento civil ou de conversão de união estável em casamento entre pessoas do mesmo sexo" (BRASIL, 2013a).Em caráter complementar, o CNJ dispôs sobre o registro da união estável em livro próprio, criando com isso o procedimento regulado pelo Provimento n. 37/2014,aplicável a esse novo ato cartorário (BRASIL, 2014b).

\section{CONSIDERAÇÕES SOBRE O ATIVISMO JUDICIAL}

Afirma-se, com muita propriedade, que uma das "expressões mais correntes atualmente nas diversas áreas do saber jurídico, mesmo sem contar com definição precisa e origem exata, é o chamado 'ativismo judicial'" (TEIXEIRA, 2012, p. 37). Mas, independentemente desse aspecto, reconhece-se que tal expressão está associada à nova concepção de integração do Direito, a partir da possível falibilidade do sistema político ${ }^{3}$, assumindo-se que o "[...] ativismo judicial representa, em última instância, a deslegitimação da Política em relação à sua tarefa essencial de buscar a realização dos valores determinados pela sociedade no cotidiano dessa mesma sociedade"(TEIXEIRA, 2012, p. 38).

\footnotetext{
${ }^{3}$ Entende-se, nesse caso, que há deslegitimação da Política em razão da inatividade ou da omissão do legislador.
} Revista de Direito Brasileira | Florianópolis, SC | v. 23 | n. 9 | p. 172-196 |Mai./Ago. 2019 
Em rigor, o movimento ativista corporificou-se de forma mais destacada no Brasilapós a promulgação da CF de 1988, especialmente com a regulamentação quanto ao modelo concentrado de controle de constitucionalidade pelo STF, aparelhado com as correspondentes ações ${ }^{4}$ e os consequentes efeitos que produzem,como a eficácia erga omnes e efeito vinculante, o que, considerado em conjunto, transforma a decisão do Tribunal em verdadeiro comando normativo, à semelhança das leis aprovadas pelo Parlamento. Consequentemente, isso criou ambiente favorável para a atuação mais incisiva e ativa do Poder Judiciário em toda sua extensão, mas especialmente pelo STF:

No Brasil, a temática relativa ao ativismo judicial só ganhou expressão com a entrada em vigor da Constituição de 1988, pois esta atribuiu uma série de prerrogativas ao magistrado, impulsionando-o, inevitavelmente, a uma atuação mais presente na sociedade (TEIXEIRA, 2012, p. 40).

Ao se examinar o modelo de controle de constitucionalidade das leis implantado no País,verifica-se que o STF passou a ter competência bastante singular esuscetível de críticas vindas dos mais diversos setores do cenário social e das demais instâncias do Estado, uma vez que suas decisões podem anular leis aprovadas pelo Parlamento.Isso ocorre na medida em que, ao se declarar a inconstitucionalidade de leis, o STF exerce atividade contrária à vontade do legislador que, nos termos definidospelo Estado Democrático, foi quem recebeu o mandato popular de representação.Situação semelhante, porém não idêntica, ocorre no controle de constitucionalidade por omissão, no qual o Tribunal, ao reconhecer a inconstitucionalidade, profere decisão que passa a integrar o ordenamento jurídico e a disciplinar a matéria, enquanto perdurar a omissão do legislador.

Mas, em torno dessa questão, é importante considerar e manter sempre presente que:

[...] a Constituição brasileira não autoriza expressamente o juiz a suprir eventual omissão legislativa para o desenvolvimento e efetivação judicial das normas constitucionais. No entanto, cumpre-se reconhecer que também não proíbe expressamente atividade dessa espécie (MORO, s.d, p. 84).

Em princípio, a decisão contramajoritária do STF, adotada em sede de controle de constitucionalidade, que expurga do ordenamento jurídico leis aprovadas pelo Parlamento nacional, parece, à primeira vista, conflitar com o referencial normativo-constitucional que assegura a independência e a harmonia entre os Poderes, uma vez que, quando "observamos prima facie a temática atinente ao ativismo judicial, uma das primeiras questões que costuma saltar os olhos é uma possível ofensa ao princípio da separação dos poderes" (TEIXEIRA, 2012, p. 41). No entanto, o que resolvidamente apresenta-se mais coerente nessa relação é que a "jurisdição constitucional não se acha de forma alguma em contradição com o princípio da separação dos poderes; ao contrário, é uma afirmação dele (KELSEN, 2007, p. 152).

Há, além disso, a possibilidade de o STF definir regramento para determinado direito em razão da omissão do Parlamento em produzir a correspondente norma, estendendo, por exemplo, o alcance de determinada lei para a regulamentação de outra realidade fática, para a qual ainda não se tenha lei específica ${ }^{5}$. Mas, ainda que seja assim, não se pode confundir as funções judiciais e legislativas ou as figuras dos juízes com os legisladores:

\footnotetext{
${ }^{4}$ Ação Direta de Inconstitucionalidade, Ação Direta de Inconstitucionalidade por Omissão, Ação Declaratória de Constitucionalidade, Mandado de Injunção, Recurso Extraordinário, Arguição de Descumprimento de Preceito Fundamental e Súmula com efeito Vinculante.

5 Tome-se como exemplo dessa situação a decisão do STF que mandou aplicar ao exercício do direito de greve dos servidores públicos a mesma legislação aplicável ao direito de greve do setor privado, uma vez que a lei exigida pela CF, para regulamentá-lo, ainda não foi produzida pelo Parlamento brasileiro.
}

Revista de Direito Brasileira | Florianópolis, SC | v. 23 | n. 9 | p.172-196 |Mai./Ago. 2019 
Por múltipla que seja a realização de diferenciação dos poderes nos vários Estados, permanecerá a diferenciação desses poderes e às divisões organizacionais de suas funções corresponde uma diversidade objetiva de atividade, ao menos para a regulação normal da competência. Uma lei não é uma sentença judicial, uma sentença judicial não é uma lei, e, sim, decisão de um "caso, com "base em uma lei". A posição especial do juiz no Estado de direito [...] baseia-se no fato de que ele decide justamente com base em uma lei e de que sua decisão, em seu conteúdo, é derivada de uma outra decisão de modo mensurável e calculável já contida na lei (SCHMITT, 2007, p. 56-57).

Evidentemente, no caso em que o STF reconheceu aplicável às relações conjugais homoafetivas as mesmas diretrizes normativas já previstas para as relações conjugais heteroafetivas, ele supriu a lacuna decorrente da omissão do Poder Legislativo, que deixou de exercer sua competência em torno dessa questão, não obstante a aclamação popular, especialmente defendida e esperada pelos casais de mesmo sexo. Nessa hipótese, a atuação do STF ajusta-se à noção ativista, no sentido positivo, compreendida como aque "se enquadra no padrão de racionalidade jurídica vigente no ordenamento e busca, em última instância, assegurar direitos fundamentais ou garantir a supremacia da Constituição" (TEIXEIRA, 2012, p. 46).Nesse sentido, é importante que se confira máxima efetividade às normas constitucionais, especialmente àquelas que consagram direitos sensíveis dos indivíduos, sendo essa tarefa atribuída ao intérprete e aplicador das normas.

Ainda em torno desse entendimento, Teixeira (2012, p. 46) classificou como nociva toda prática ativista que fuja desse quadro ou busque, sobretudo, fazer preponderar um padrão de racionalidade eminentemente político. Em razão disso,explicou que:

[...] a forma mais nociva de ativismo judicial é aquela que vincula o julgador a um setor ou setores sociais específicos, em detrimento de indivíduos cujos interesses se encontram juridicamente protegidos, os quais teriam no Judiciário o espaço derradeiro para a sua proteção.

A nocividade maior do ativismo judicial ocorre quando a decisão judicial tem um fim político e depende da negação à tutela de interesses legítimos de alguma parte da ação, fundamentando-se em argumentos que transcendem a racionalidade jurídica (TEIXEIRA, 2012, p. 48).

De fato, em casos como esse, o STF teve atuação que, analogicamente, pode ser comparada à de "legislador positivo"6, postura que dividiu os críticos em suas opiniões, havendo aqueles que concordam e aqueles que discordam quanto a essa possibilidade de ingerência pelo Tribunal. Nesse aspecto, o ativismo judicial ora é aclamado como atributo necessário e até recomendável para a manutenção e o equilíbrio do ordenamento jurídico funcional; ora, porém, é aclamado em tom pejorativo, como se tal fosse um absurdo do ponto de vista político e jurídico, o que alguns consideram verdadeira invasão da competência de um Poder pelo outro.Mas, certamente, a nova realidade vivenciada pelo Tribunal segue na linha de ajustes de suas competências, notadamente em razão de seu (novo) desempenho institucional e político:

Em decorrência das alterações introduzidas pela Emenda Constitucional 45/04 e pela própria mudança da composição do Supremo Tribunal Federal a partir de 2003, é possível perceber uma espécie de ativismo judicial, eminentemente formal e preocupado com a redefinição das competências do próprio STF, como

\footnotetext{
${ }^{6}$ Ao contrário disso, quando o Tribunal, agindo no exercício do controle de constitucionalidade, retira do ordenamento jurídico lei em vigor, sua atuação pode ser equiparada à de um "legislador negativo".
} 
um processo autônomo por parte de nossa jurisdição constitucional. Esta redefinição institucional, operada com o auxílio da noção de mutação constitucional, [...], é norteadasobretudo pelos ideais de concentração e de vinculação das decisões do Supremo Tribunal Federal (VALLE, 2009, p. 37).

A par dessas considerações, já se pode adotar um conceito de ativismo judicial:

[...] se refere à postura dos membros do Poder Judiciário que se valem de uma interpretação expansiva e abrangente do texto constitucional, ampliando o alcance de suas normas, para contornar a inércia ou insuficiência do trabalho dos Poderes políticos (ARANHA FILHO; ARANHA, 2014, p. 314).

E isso decorre da circunstância de que:

[...] o ativismo é uma atitude, a escolha de um modo específico e proativo de interpretar a Constituição, expandindo o seu sentido e alcance. Normalmente, ele se instala - e este é o caso do Brasil - em situações de retração do Poder Legislativo, de um certo descolamento entre a classe política e a sociedade civil, impedindo que determinadas demandas sociais sejam atendidas de maneira efetiva (BARROSO, 2014b, p. 246-247).

Conclui-se, portanto, queo ativismo é instrumento de atuação judicial, de caráter político e jurídico, que tem sido empregado também como alternativa em face da omissão legislativa reputada inconstitucional.

\section{A POSIÇÃO CONTRAMAJORITÁRIA DO SUPREMO TRIBUNAL FEDERAL}

Num cenário social que compreende comportamentos, interesses e novas dinâmicas, todos regulados pela moderna ordem constitucional,mais aberta e liberal, é natural, e até exigível, que o Estado, por intermédio de seus mais diversos órgãos de atuação administrativa e política, se ajuste a essa realidade, de modo a acompanhar as tendências e as transformações e, em particular, rever conceitos, que podem estar ultrapassados.

Percebendo a possibilidade de o Poder Legislativo não corresponder prontamente às expectativas geradas no contexto da nova realidade socialque se estabeleceu com a CF de 1988, especialmente quanto aos direitos de cidadania, o legislador constituinte assegurou a possibilidade de o STF reconhecer e declarar a inconstitucionalidade por omissão, de modo a tornar efetiva norma constitucional, atendendo-se ao disposto no $\S 2^{\circ}$ do art. 103 da Constituição. Essa questão, não obstante, representa muito mais que simples opção do constituinte originário, uma vez que se refere e se associa mais proximamente com o processo de judicialização dos "casos difíceis" implantado pelo regime constitucional em vigor:

Um dos traços mais marcantes do Estado constitucional contemporâneo é a ascensão institucional do Poder Judiciário. Tal fenômeno se manifesta na amplitude da jurisdição constitucional, na judicialização de questões sociais, morais e políticas, bem como em algum grau de ativismo judicial [...] (BARROSO, 2015, p. 530-531).

Mas, independentemente disso, a verdade é que com a Constituiçãode 1988 surgiu nova proposta de interpretação constitucional, necessária para atenderas demandas da sociedade, agora mais complexa e plural (BARROSO, 2014b, p. 36) e, obviamente, essa complexidade e pluralidade proporcionaram o surgimento de demandas ancoradas em novos valores e princípios, exigindo maior esforço argumentativo em torno de questões antes não enfrentadas, como a

Revista de Direito Brasileira | Florianópolis, SC | v. 23 | n. 9 | p.172-196 |Mai./Ago. 2019 
dignidade da pessoa humana, por exemplo. Em consequência, de acordo com Barroso (2014b,p.38), a solução para os "casos difíceis"deverá ser construída argumentativamente e mediante ponderação, compreendendo-se como "casos difíceis":

[...] aqueles que, devido a razões diversas, não têm uma solução abstratamente prevista e pronta no ordenamento, que possa ser retirada de uma prateleira de produtos jurídicos. Eles exigem a construção artesanal da decisão, mediante uma argumentação mais elaborada, capaz de justificar e legitimar o papel criativo desempenhado pelo juiz na hipótese (BARROSO, 2014b, p. 38).

Em razão dessa nova realidade, verifica-se que a prudência do legislador constituinte não foi em vão nem desprovida de fundamentos, pois o que cogitou no plano teórico quanto à omissão do legislador ordinário (previsão) revelou-se de forma concreta em várias hipóteses,entre as quais se pode citar,como exemplo, a falta de legislação que disponha sobre os direitos e os deveres decorrentes da união estável homoafetiva. Consequentemente, a posição ativa do STF rumo ao equacionamento desse problema foi a única medida possível e efetivamente concretizada para o resguardo dos direitos em disputa diante do vínculo de união homoafetiva.Nesse contexto, a crítica reconhece e ressalta que "a atividade do legislador negativo, da jurisdição constitucional, é absolutamente determinada pela Constituição" (KELSEN, 2007, p. 153).

Esse cenário, de fato, é bastante complexo, uma vez que envolve engenharia jurídica e política, que conjugaforças a partir do hiato legislativo e da supressão deste com a produção da decisão judicial integradora. Desse modo, se por um lado, atendendo-se ao princípio da Separação dos Poderes, cabe ao Poder Legislativo a competência para editar as leis necessárias ao pleno exercício dos direitos inerentes à cidadania e de outros valores constitucionais, por outro lado, antevendo-se a possibilidade de o Poder Legislativo se manter omisso diante de algumas matérias de relevante interesse social, individual ou coletivo, incumbirá ao Poder Judiciário o dever de suprir tal omissão, decidindo e determinando a solução para o caso concreto, com eficácia erga omnes e efeito vinculante.Mas, inegavelmente, essa separação de competências abriu caminho para outra discussão afim: definir limites entre a Política e o Direito:

A separação entre Direito e política tem sido considerada como essencial no Estado constitucional democrático. Na política, vigoram a soberania popular e o princípio majoritário. O domínio da vontade. No Direito, vigora o princípio da lei (the rule of law) e do respeito aos direitos fundamentais. O domínio da razão (BARROSO, 2015, p. 448).

Nesse sentido, a decisão do STF, tomada em sede de controle de omissão inconstitucional, não apenas supre a lacuna legislativa, como também opera o efeito prático de lei, resolvendo o processo paradigma e criando precedentes para a solução de casos futuros:

Em toda Constituição escrita existe o princípio implícito de que todo comportamento a ela contrário reveste-se de ilicitude, o que decorre de sua própria supremacia. Se se tratar de inconstitucionalidade por ação, o princípio exige a invalidação retroativa do ato ilícito, salvo se existirem razões superiores em sentido contrário. Se se tratar de inconstitucionalidade por omissão, o princípio exige o seu suprimento, nas mesmas circunstâncias (MORO, s.d, p. $85)$.

Mas, diante desse cenário, é inevitável que o STF, ao suprir a omissão legislativa, avance no ambiente da competência reservada ao Parlamento: 
O julgador, no exercício do controle de constitucionalidade, invade inevitavelmente área reservada ao legislador. Assim age, entretanto, para resguardar a supremacia da Constituição. Aliás, a intensidade da interferência parece ser maior no caso de invalidação de ato legislativo inconstitucional do que no de suprimento da omissão inconstitucional. [...] Se em um regime democrático são problemáticas decisões judiciais que invadam decisões legislativas, menos problemáticas são decisões judiciais que suprem vazios legislativos (MORO, s.d, p. 86).

Convenha-se, entretanto, que essa nova circunstânciacaracterizadorada atuação do Poder Judiciário é menos afrontosa ao princípio da Separação dos Poderes, conforme destacado, e mais acertadamente constitui-se numa técnica constitucional para o enfrentamento de problemas da sociedade moderna, complexa e plural:

Em muitas situações, em lugar de se limitar a aplicar a lei já existente, o juiz se vê na necessidade de agir em substituição ao legislador. A despeito de algum grau de subversão ao princípio da separação dos Poderes, trata-se de uma inevitabilidade, a ser debitada à complexidade e ao pluralismo da vida contemporânea. Foi o que ocorreu no exemplo do reconhecimento das uniões homoafetivas (BARROSO, 2014b, p. 41).

Tudo isso leva a outra reflexão: o fato de que, com a promulgação da CF de 1988, o Poder Judiciário brasileiro experimentou visível e profundo processo expansionista, em decorrência do reforço substancial do catálogo de direitos fundamentaisincorporado. A positivação de direitos fundamentais e, paralelamente, a incorporação de mecanismos de garantia desses direitos, impulsionaram o Poder Judiciário rumo a uma extraordinária expansão, que não ficou limitada ao campo de sua estruturação e especializações, alcançando, no mais, uma ideologia de atuação. Em torno dessa questão, os chamados "conceitualistas" procuraram explicar esse processo de crescimento:

[...] a principal causa de expansão do Judiciário teria sido a ampliação da positivação e da consciência sobre direitos que se verificou a partir do segundo pós-guerra, na linha do que é definido pelo conhecimento jurídico convencional (BRANDÃO, 2013, p. 213).

Seguindo nessa linha, é de se esperar que no centro de um Poder ativista esteja presente o correspondente juiz ativista, que busca efetivar a Constituição:

Um juiz ativista, em sentido positivo, atua na busca da proteção dos direitos fundamentais e da garantia da supremacia da Constituição, assumindo uma postura concretizadora quando diante de princípios constitucionais [...] (TEIXEIRA, 2012, p. 48).

Estas ponderações prestam-se apenas para situar que a atuação contramajoritária desempenhada pela Corte constitucional é mais uma de suas competências programadas pela própria Constituição:

[...] em nome da Constituição, da proteção das regras do jogo democrático e dos direitos fundamentais, cabe a ela [Corte constitucional] a atribuição de declarar a inconstitucionalidade das leis (i.e., de decisões majoritárias tomadas pelo Congresso) e de atos do Poder Executivo (cujo chefe foi eleito pela maioria absoluta dos cidadãos). Vale dizer: agentes públicos não eleitos, como juízes e 
Ministros do STF, podem sobrepor a sua razão à dos tradicionais representantes da política majoritária. Daí o termo contramajoritário (BARROSO, 2015, p. 476).

E, por essa razão, não se pode ignorar que a legitimação para interpretar e aplicar a Constituição é algo que não se limita ao espectro restrito da atuação dos representantes eleitos:

A legitimidade política não decorre apenas da representação por via eleitoral, que autoriza os parlamentares a tomarem decisões em nome do povo. Ao lado dos conceitos de eleições e do princípio majoritário, a ideia de democracia deliberativa não só comporta como exige um outro componente: uma representação argumentativa ou discursiva. O constitucionalismo democrático se funda na institucionalização da razão e da correção moral. Isso significa que uma decisão da Corte suprema, para ser inquestionavelmente legítima, deverá ser capaz de demonstrar: (i) a racionalidade e a justiça do seu argumento, bem como (ii) que ela corresponde a uma demanda social objetivamente demonstrável (BARROSO, 2015, p. 477).

Desse modo, como resultado das modificações experimentadas pelo Poder Judiciário, no contexto do novo ideário democrático, o cidadão encontra-se duplamente representado, a partir da técnica integrativa da ordem jurídica e da distinção precisa entre representação política e argumentativa:

O parlamento representa o cidadão politicamente, o tribunal constitucional, argumentativamente. Com isso, deve ser dito que a representação do povo pelo tribunal constitucional tem um caráter mais idealístico do que aquela pelo parlamento (ALEXY, 2007, p. 53-54).

Essas reflexões permitem afirmar que a democracia majoritarista é a mesma que constituiu os mecanismos políticos e jurídicos que respaldam a atuação contramajoritária do STF, o que igualmente permite situar o ativismo judicial como fator perfeitamente ajustável aos referenciais democráticos e constitucionais hoje existentes. Aliado a isso, a atuação do intérprete constitucional deságua, inevitavelmente, no campo próprio da democracia representativa, como consequência natural do desempenho de suas funções constitucionais, não apenas jurídicas, mas também políticas:

[...] como cabe à jurisdição constitucional a última palavra na interpretação da Constituição, que se apresenta agora repleta de valores impositivos para todos os órgãos estatais, não surpreende que o juiz constitucional assuma terminante influência sobre as deliberações políticas de órgãos de cunho representativo(BRANCO, 2009, p. 60).

\section{O REGIME DEMOCRÁTICO FAVORECE O ATIVISMO JUDICIAL}

A verdade, no entanto, é que não se pode assumir que o ativismo seja sempre um mal e que o juiz ativista seja um vilão, que se aproveita da situação para impor sua vontade em detrimento dos representantes do povo, democraticamente eleitos, e da vontade do próprio povo, embora essa possibilidade não possa ser ignorada. Ainda assim, o fato a ser considerado é que o povo, seus representantes no Parlamento e os próprios juízes, todos, indistintamente, participam do regime democrático, mesmo que suas idealizações políticas sejam distintas. 
Nesse jogo político e de forças, não se pode dizer que o povo e seus representantes eleitos repudiem a atuação ativista do judiciário, tendo em vista a peculiar situação verificada de forma insistente e reiterada em que todos têm se valido cada vez mais da Jurisdição, como alternativa para o encaminhamento desoluções de problemas políticos e jurídicos das mais diversas espécies. Em acréscimo, mas ainda a propósito dessa discussão, impõe-se reconhecer que:

A democracia representativa talvez seja, antes de tudo, um sistema de governo apropriado àquelas situações nas quais por algum motivo é impraticável que os cidadãos participem diretamente do processo legislativo (ELY, 2010, p. 103).

Nessa seara, o que se revela com grande transparência é que o próprio regime democrático não apenas favorece, como também estimula as práticas ativistas, o que visto com absoluta isenção e imparcialidade parece ser um paradoxo da democracia. Mas, a bem da razão, não poderia ser de outra maneira, ainda mais se se considerar que, tratando-se de decisão judicial ativista, que supre omissão inconstitucional, nada impede que o Poder Legislativo edite a norma, subsequentemente, pondo fim ao vazio normativo e, agora, com a vantagem de que a que viera ser produzida não será considerada inconstitucional, ao menos enquanto a composição do STF se mantiver inalterada ou formada em sua maioria por aqueles integrantes que julgaram a favor da decisão tida como ativista.Não obstante, verifica-se que até o presente momento ainda não foi editada qualquer norma, pelo Parlamento brasileiro, que disponha sobre os direitos e os deveres dos casais homossexuais.

Outro aspecto que merece destaque é que o regime democrático instalado no País com a promulgação da CF de 1988 elevou consideravelmente o número de questões, talvez antes triviais, ao patamar de temas constitucionais relevantes, operando, com isso, a expansão das demandas judiciais, especialmente no âmbito da competência do STF. Vê-se com isso que o próprio regime democrático abriu as portas da Corte constitucional para receber as demandasque não foram resolvidas pelo Parlamento, a tempo e modo. Consequentemente, a ampla positivação de direitos associada à inércia e à lentidão do Parlamento, em dar respostas rápidas e eficientes, fez com que ocorresse vertiginosa expansão do processo de judicialização das demandas individuais e sociais, oportunizando, com isso, a maximização dessas intervenções que, depois, passariam a ser rotuladas de ativistas:

No Brasil, o fenômeno assume uma proporção maior em razão de a Constituição cuidar de uma impressionante quantidade de temas. Incluir uma matéria na Constituição significa, de certa forma, retirá-la da política e trazê-la para o direito, permitindo a judicialização (BARROSO, 2014b, p. 39).

Diante dessa realidade, apontam-se as possíveis razões que mudaram o centro de tomada de decisões, passando-o do Legislativo para o Judiciário:

A primeira é o reconhecimento de que um Judiciário forte e independente é imprescindível para a proteção dos direitos fundamentais. A segunda envolve uma certa desilusão com a política majoritária. Há uma terceira: atores políticos, muitas vezes, para evitar o desgaste, preferem que o Judiciário decida questões controvertidas, como aborto e direitos dos homossexuais (BARROSO, 2014b, p. 39).

Examinando esse ponto de vista, não se pode deixar de refletir quanto a outro aspecto intimamente relacionado, que evidencia o profundo sentimento de descrédito e de insatisfação da população com o Parlamento e com os rumos da política: 
Uma certa decepção e suspeita com relação ao Parlamento e ao Executivo, agravada pela falta de partidos solidamente estruturados, pode ser vista como fator para que as expectativas populares se orientassem a um novo endereço, aquele dos tribunais constitucionais, fortalecendo as Cortes e as elevando à condição de peças fundamentais para a preservação e estímulo dos elementos democráticos da vida política (BRANCO, 2009, p. 128/129).

Mas não se pode ignorar que os opositores do ativismo judicial têm fundamentos sérios e razoáveis, que também precisam ser considerados. O primeiro deles, e talvez o mais contundente, refere-se à circunstância de que os juízes não são eleitos, de modo que suas decisões não poderiam sobrepor-se às dos representantes eleitos. Outra crítica é a de que o Judiciário é um espaço conservador, que preserva as elites contra os chamados processos democráticos majoritários (BARROSO, 2014b, p. 40).

Esses pontos de vista, a bem da verdade, têm certo grau de coerência, mas, refutando-os, há de se considerar, primeiramente, que os juízes têm acesso a seus respectivos cargos, nas várias instâncias do Poder Judiciário, respeitando-se e cumprindo-se as exigências que o modelo democrático prescreveu, tanto quanto o fez quanto à investidura dos representantes do povo nas casas legislativas. Em outras palavras, no Brasil, embora os juízes não tenham recebido legitimidade pelo voto popular direto, eles foram investidos de autoridade segundo os regramentos dispostos na Constituição, que definiu os limites das competênciase ainda resolveusobre o procedimento a ser adotado quando houver omissões reputadas inconstitucionais, além do fato de que esses regramentos foram produzidos pelos próprios representantes do povo no Parlamento:

Os métodos de atuação e de argumentação dos órgãos judiciais são, como se sabe, jurídicos, mas a natureza de sua função é inegavelmente política [...]. Sem embargo de desempenhar um poder político, o Judiciário tem características diversas das dos outros Poderes. É que seus membros não são investidos por critérios eletivos nem por processos majoritários. E é bom que seja assim. A maior parte dos países do mundo reserva uma parcela de poder para que seja desempenhado por agentes públicos selecionados com base no mérito e no conhecimento específico. Idealmente preservado das paixões políticas, ao juiz cabe decidir com imparcialidade, baseado na Constituição e nas leis. Mas o poder de juízes e tribunais, como todo poder em um Estado democrático, é representativo. Vale dizer: é exercido em nome do povo e deve contas à sociedade (BARROSO, 2014b, p. 228-229).

Não se pode dizer, ademais, que o Legislativo não seja conservador e que não tenha interesses elitistas a preservar, como os são os interesses associados ao fator do capital político, espécie de moeda política essencial para definir, influenciar e separar os que serão eleitos e os que não serão.Aliado a isso, como a democracia não é atributo exclusivo do Poder Legislativo,ela prescreve que esse Poder tem legitimidade política para legislar, enquanto o Poder Judiciário tem legitimidade jurídica para suprir omissões legislativas inconstitucionais, entre outras competências. Alias, ainda a propósito dessa discussão, Suzanna Sherry entende que o problema não é o ativismo em si, mas a própria decisão ativista. Segundo ela, as controvérsias surgidas nessa seara dizem respeito à correção da decisão tomada pelo tribunal e não sobre sua legitimidade (SHERRY, 2013, p. 4).

Além disso, há um aspecto que a democracia impõe ao juiz, ativista ou não, quanto ao desempenho de suas funções, no que tange mais propriamente com a fundamentação de suas decisões. De fato, o juiz deve fundamentar suas decisões, sendo essa circunstância pressuposto de validade delas. Ao contrário, porém,o legislador não está obrigado, por exemplo, a justificar sua 
omissão sobre assuntos relevantes de interesse geral, o que dificulta ao eleitorado compreender de forma clara as razões da inércia.Não obstante, o fato é que tudo isso se encontra albergado na mesma estrutura do Estado de Direito e, portanto, é fruto do regime democrático:

[...] as decisões dos juízes repousam sobre a interpretação das leis existentes e sobre os precedentes pertinentes [...], os juízes devem justificar seus veredictos com referência a essas interpretações e adotar uma interpretação coerente de um caso a outro, ou então justificar com base razoável as diferenças entre eles, e assim por diante. Os legisladores não estão ligados por cerceamentos desse tipo; apesar de não terem o direito de desafiar a lei básica, e de não poderem tentar politicamente mudá-la, a não ser dentro dos limites da constituição, eles não precisam explicar nem justificar seu voto, mesmo que seus eleitores possam pedir-lhes que prestem contas (RAWLS, 2000, p. 371).

\title{
6 INATIVIDADE E OMISSÃO DO PODER LEGISLATIVO
}

\author{
O legislador não está imune aos comandos da Constituição e sua insubmissão pode \\ caracterizar omissão inconstitucional:
}

[...] nos casos em que a Constituição impõe ao órgão legislativo o dever de editar norma reguladora da atuação de determinado preceito constitucional, sua abstenção será ilegítima e configurará caso de inconstitucionalidade por omissão (BARROSO, 2015, p. 258).

De fato, há alguns casos resultantes daomissão do legislador que se tornaram frequentes e repetitivos, impondo-se às partes interessadas buscar as respostas às suas demandas perante o STF. Tais situações caracterizaram-se especialmente por constituir problemas sociais e individuais relevantes, cujas soluções estão previstas na Constituiçãoe exigem a edição de normas regulamentadoras. Em várias situações, o "vácuo legislativo"ainda persiste, de modo que a intervenção do STF, para a solução de demandas concretamente definidas, foi e continua sendo a única possibilidade de atendimento e resposta ao jurisdicionado.

Há alguns exemplos dessa realidade que são oportunos e exemplificativos.

Demanda D1: aConstituição estabeleceu critérios uniformes para o regime de aposentadoria no serviço público, mas excepcionou algumas regras apenas para os portadores de deficiência, para os servidores que exerçam atividades consideradas de risco e em relação as atividades exercidas em condições especiais que prejudiquem a saúde ou a integridade física do servidor. Desse modo, para regulamentar o regime de aposentadoria aplicável às indicadas exceções exigiu-se a edição de lei complementar (LC), nos termos do $\S 4^{\circ}$, do art. 40, da CF.

Entretanto, com o passar do tempo, foram numerosos os casos envolvendo servidores que exerciam atividadesque se enquadravam nas exceções relacionadas no indicado dispositivo constitucional, mas ainda assim o Parlamento não editou a exigida lei complementare, por essa razão, os titulares do direito à aposentadoria especial ajuizaram Mandados de Injunção no STF, visando a obter provimentos que lhes assegurasse o pleno exercício desse direito. Consequentemente, após examinar as incontáveis demandas em sede de Mandado de Injunção, o STF editou a Súmula Vinculante n. 33, com o seguinte teor:

Aplicam-se ao servidor público, no que couber, as regras do regime geral da previdência social sobre aposentadoria especial de que trata o artigo 40, $\S 4^{\circ}$, inciso III, da Constituição Federal, até a edição de lei complementar específica (BRASIL, 2014d). 
Anteriormente, nesse mesmo sentido, o Tribunal já havia fixado o precedente:

Mandado de injunção. Aposentadoria especial do servidor público. Artigo 40, § $4^{\circ}$, da Constituição da República. Ausência de lei complementar a disciplinar a matéria. Necessidade de integração legislativa. 1. Servidor público. Investigador da polícia civil do Estado de São Paulo. Alegado exercício de atividade sob condições de periculosidade e insalubridade. 2. Reconhecida a omissão legislativa em razão da ausência de lei complementar a definir as condições para o implemento da aposentadoria especial. 3. Mandado de injunção conhecido e concedido para comunicar a mora à autoridade competente e determinar a aplicação, no que couber, do art. 57 da Lei n. 8.213/91 (BRASIL, 2009, p. 78).

É curioso observar, na abordagem desse tema, que foi editada a LC n. 144/2014, com a finalidade de regulamentar o dispositivo constitucional em comento exclusivamente em relação aos servidores policiais, de modo que quanto aos demais servidores e portadores de deficiências, que se enquadram nas exceções especificadas, ainda persiste a omissão inconstitucional, reservando-se para estes a aplicação da Súmula Vinculante n. 33 do STF.

Demanda D2: a Constituição também proclamou o direito de greve dos servidores públicos, em conformidade com o inc. VII, do art. 37, da CF,condicionando-se o exercício desse direito aos termos e limites a serem definidos em lei específica. Entretanto, de igual modo, tal lei ainda não foi editada e, por essa razão, inúmeras ações têm sido ajuizadas visando a correção dessa omissão. Ao enfrentar inúmeras demandas em torno dessa matéria, o STF reconheceu não apenas a legitimidade do direito à grave pelo servidor público, como também integrou a lacuna existente, determinando fosse aplicado como regramento do direito de greve do servidor público a Lei n. 7.783/1989, que regulamenta o direito de greve no setor privado.

Acerca dessa questão, no voto proferido pelo Min. Celso de Mello, asseverou-se que:

A inércia estatal em adimplir as imposições constitucionais traduz inaceitável gesto de desprezo pela autoridade da Constituição e configura, por isso mesmo, comportamento que deve ser evitado, pois nada mais nocivo, perigoso e ilegítimo do que elaborar uma Constituição, sem a vontade de fazê-la cumprir integralmente, ou, então, de apenas executá-la com o propósito subalterno de torná-la aplicável somente nos pontos que se revelarem convenientes aos desígnios dos governantes, em detrimento dos interesses maiores dos cidadãos (BRASIL, 2007, p. 135).

Demanda D3: a Constituição estabeleceu que o direito ao aviso prévio proporcional ao tempo de serviço, tratado no art. $7^{\circ}$, inc. XXI, deverá ser definido em lei. Para atender a essa finalidade foi editada a Lei n. 12.506/2011, tendo sido suprida a lacuna legislativa que persistiu durante quase duas décadas e meia, sendo que durante todo esse tempo o STF declarou, reiteradamente, a mora legislativa do Congresso Nacional, acolhendo e julgando procedentes incontáveis Mandados de Injunção:

Mandado de injunção. 2. Aviso prévio proporcional ao tempo de serviço. Art. $7^{\circ}$, XXI, da Constituição Federal. 3. Ausência de regulamentação. 4. Ação julgada procedente. 5. Indicação de adiamento com vistas a consolidar proposta conciliatória de concretização do direitoao aviso prévio proporcional. 6. Retomado o julgamento. 7. Advento daLei 12.506/2011, que regulamentou o direito ao aviso prévio proporcional.8. Aplicação judicial de parâmetros idênticos aos da referida legislação. 9.Autorização para que os ministros apliquem monocraticamente esseentendimento aos mandados de injunção pendentes de julgamento, desdeque impetrados antes do advento da lei 
regulamentadora. 10. Mandadode injunção julgado procedente (BRASIL, 2013b, p. 1).

Há, além dessas situações, outras particularidades da omissão legislativa que não estão diretamente ligadas a grande massa populacional, mas que igualmente ainda reclamam a atividade legislativa necessária à produção do comando normativo que irá integrar a norma constitucional.

Demanda D4: o primeiro exemplo, diz respeito com a mora legislativa quanto à norma que deverá disciplinar o acesso de auditores e membros do Ministério Públicoaos respectivos Tribunais de Contas Estaduais ${ }^{7}$. Nesse passo, a Constituição definiu, primeiramente, o regramento aplicável em relação ao Tribunal de Contas da União, na forma do $\S 2^{\circ}$, do art. 73 e, em conformidade com o art. 75, dispôs que tal norma deverá ser aplicada quanto à organização, à composição e à fiscalização no âmbito dos tribunais estaduais e dos conselhos municipais, desse mesmo gênero:

1. A nomeação livre dos membros do Tribunal de Contas do Estado e do Tribunal de Contas dos Municípios pelo Governador dar-se-á nos termos do art. 75 da Constituição do Brasil, não devendo alongar-se de maneira a abranger também as vagas que a Constituição destinou aos membros do Ministério Público e aos auditores. Precedentes.

2. O preceito veiculado pelo artigo 73 da Constituição do Brasil aplica-se, no que couber, à organização, composição e fiscalização dos Tribunais de Contas dos Estados e do Distrito Federal, bem como dos Tribunais e Conselhos de Contas dos Municípios. Imposição do modelo federal nos termos do artigo 75.

3. A inércia da Assembléia Legislativa cearense relativamente à criação de cargos e carreiras do Ministério Público Especial e Auditores que deve atuar junto ao Tribunal de Contas estadual consubstancia omissão inconstitucional.

4. Ação direta de inconstitucionalidade por omissão julgada procedente (BRASIL, 2005, p. 1).

Demanda D5: a regulamentação por lei quanto à criação de Municípios é outro exemplo deinércia que gera perplexidadesno campo da omissão legislativa.Essa questão é mais intrigante, entendendo-se que a Constituição passou a exigir a edição de lei complementar para a regulamentação quanto a criação, a incorporação, a fusão e o desmembramento de Municípios, na forma estabelecida no art. 18, § $4^{\circ}$, nos termos da Emenda à Constituição n. 15/1996.Contudo, para atingir a finalidade definida com a nova redação dadapela Emenda, foi apresentado projeto de lei complementar ${ }^{8}$ que, após a tramitação devida, foi aprovado e encaminhado à sanção presidencial. Não obstante, o projeto em questão foi vetado pelo Poder Executivo (BRASIL, 2014c) e, após, ao retornar ao Poder Legislativo, o referido veto foi mantido (BRASIL, 2014a, p. 146).

\footnotetext{
${ }^{7}$ Lembrando-se que são competências dos Estados quanto aos seus Tribunais de Contas e respectivos Conselhos de Contas.

${ }^{8}$ O projeto de lei complementar tramitou na Câmara dos Deputados como PLP n. 397/2014 e no Senado como PLS n. $104 / 2014$.
} 
Tabela 2 - Síntese da Atual Situação de Casos de Omissão Inconstitucional.

\begin{tabular}{|c|c|c|}
\hline \multicolumn{3}{|c|}{ CASOS DE OMISSÃO INCONSTITUCIONAL } \\
\hline DEMANDA & SITUAÇÃO & OBSERVAÇÃO \\
\hline D1 & Parcial & LC n. 144/2014. \\
\hline D2 & Total & --- \\
\hline D3 & Resolvida $^{9}$ & Lei n. 12.506/2011. \\
\hline D4 & Total $^{10}$ & -- \\
\hline D5 & Total & Veto total ao PLS 104/2014.Veto mantido pelo Congresso Nacional. \\
\hline
\end{tabular}

Todos esses casos evidenciam muito mais que a omissão inconstitucional, uma vez que também denunciam a ausência de mecanismos políticos e jurídicos consistentes e aptos a impor ao Poder Legislativo que exerça suas competências declinadas na Constituição:

A omissão inconstitucional pressupõe um dever constitucional de legislar, que tanto pode ser derivado de ordens concretas contidas na Lei Fundamental, quanto de princípios desenvolvidos mediante interpretação (MENDES, 1998, p. 48).

Com efeito, a Ação Direta de Inconstitucionalidade por Omissãoe o Mandado de Injunção, previstos como categoria de ações jurídico-constitucionais, são valorosos mecanismosincorporados pela democracia como técnica destinada à proteção dos direitos individuais aplicáveis sempre que a falta de norma específica inviabilize o exercício de direitos, mormente aqueles relacionados com o exercício da cidadania:

Nos termos do art. 103, $\S 2^{\circ}$, da Constituição Federal, a ação direita de inconstitucionalidade por omissão visa a tornar efetiva norma constitucional, devendo ser dada ciência ao Poder competente para adoção das providências necessárias $[\ldots]$

Objeto desse controle abstrato da inconstitucionalidade é a mera inconstitucionalidade morosa dos órgãos competentes para a concretização da norma constitucional (MENDES; BRANCO, 2012, p. 1332).

O mandado de injunção há de ter por objeto o não cumprimento de dever constitucional de legislar que, de alguma forma, afeta direitos constitucionalmente assegurados (falta de norma regulamentadora que torne inviável o exercício de direitos e liberdades constitucionais e das prerrogativas inerentes à soberania e à cidadania) (MENDES; BRANCO, 2012, p. 1359).

Na linha desses entendimentos, concluiu-se que:

A Constituição de 1988 abriu a possibilidade para o desenvolvimento sistemático da declaração de inconstitucionalidade sem a pronúncia de nulidade, na medida em que atribuiu particular significado ao controle de constitucionalidade da chamada "omissão de legislador". O art. $5^{\circ}$, LXXI, da Constituição previu, expressamente, a concessão do mandado de injunção sempre que a falta de norma regulamentadora tornar inviável o exercício dos direitos e liberdades constitucionais e das prerrogativas inerentes à nacionalidade, à soberania e à cidadania.

\footnotetext{
${ }^{9}$ Nesse caso, a omissão inconstitucional somente foi resolvida depois de decorridos 23 anos.
}

${ }^{10}$ Refere-se à omissão inconstitucional da Assembleia Legislativa do Estado do Ceará. 
A adoção pela Constituição brasileira de instituto especial, destinado à defesa dos direitos subjetivos constitucionalmente assegurados contra a omissão do legislador, não dá ensejo a qualquer dúvida quanto à configuração de direito subjetivo público a uma ação positiva de índole normativa por parte do legislador (MENDES, 1998, p. 53).

Com isso, o que se pode inferir do sistema de direitos e garantias instituído pela Constituição de 1988 é que, enquanto a omissão inconstitucional do Poder Legislativo decorre da violação do dever de legislar e de sua insubmissão aos mandamentos constitucionais, a inatividade legislativa, que igualmente prejudica o exercício de direitos,pode ser atribuída às conveniências e opções políticas e, também, às limitações do Parlamento em produzir as articulações necessárias ao cumprimento de seu dever institucional ante o eleitorado. Tudo isso evidencia, no mais, a ausência do espírito público vocacionado do legislador, que optou por deixar a cargo do Poder Judiciário a complementação das normas reclamadas pela Constituição, com o propósito de evitaros consequentes desgastes políticos ${ }^{11}$.

Vale destacar que a omissão legislativa não guarda convergência com uma inércia política. Há, sim, ausência de condições políticas para a construção de consenso hábil a permitir a normatização de direitos constitucionalmente estabelecidos. A positivação de direitos na Carta Política não traduz imediatamente a sua concretização. São as garantias — jurídicas, políticas, econômicas, culturais etc. — que instrumentalizam a fruição desses direitos. A omissão legislativa na concretização dessas garantias evidencia a falta de consenso para o desenho dos arranjos normativos e institucionais necessários à fruição desses direitos.

Por isso, a omissão legislativa que dá azo ao ativismo judicial não admite explicação numa suposta inércia política. O silêncio do Parlamento evidencia, ao menos no campo político, grande significado. No entanto, a concretização de direitos marcados pela fundamentalidade não pode se condicionar pelo momento de construção desse consenso político para produção legislativa. Por isso, o ativismo muitas vezes se apresenta antes ou concomitante ao processo de consolidação legislativa desses direitos constitucionalmente previstos no campo político.

Desse modo, compreende-se o inativismo legislativo como exercício do oportunismo, estratégia que se ancora noutro patamar, que corresponde às opções do legislador fundadas em suas conveniências e discricionariedade políticas. E, em consequência disso, concluiu-se com preciso acerto que "o Judiciário se expande, sobretudo, na situação em que o Legislativo não pode, não quer ou não consegue atuar" (BARROSO, 2014b, p. 41-42).

\section{O INDIVÍDUO ENTRE O ATIVISMO JUDICIAL E O INATIVISMO LEGISLATIVO}

O principal foco de abordagem desenvolvido ao longo deste artigo ocupou-se em demonstrar que o ativismo judicial é consequência imediata do inativismo legislativo, o que se pode resumir nos seguintes argumentos:

[...] o ativismo judicial é reação do Poder Judiciário à ineficácia do Poder Legislativo no exercício de suas funções típicas, isto é, editar normas gerais e abstratas depois de maturados debates políticos. A atuação deficiente do Parlamento é, portanto, simultaneamente uma das origens e fomento do ativismo (BOCCATO, 2015, p. 68).

[...] o ativismo judicial representa a insuficiência do Estado em atender aos anseios da sua população, bem como em buscar a realização dos objetivos que

\footnotetext{
${ }^{11}$ Esse desgaste político, no enfrentamento de questões complexas, como é o caso da regulamentação da união estável homoafetiva, pode ocorrer com os setores mais conservadores da sociedade ou com algumas designações religiosas, defensoras da família e do casamento tradicionais.
}

Revista de Direito Brasileira | Florianópolis, SC | v. 23 | n. 9 | p.172-196 |Mai./Ago. 2019 
lhe foram postos: trata-se de uma patologia constitucional (TEIXEIRA, 2012, p. 50).

Alguns tribunais, diante da inércia dos políticos e da impossibilidade de negarem uma decisão, são obrigados a pôr um fim em conflitos que deveriam ser resolvidos no âmbito político (CARVALHO, 2004, p. 120).

Convenha-se, não obstante, que tudo isso é tecnicismo jurídico e político, que está longe da percepção e da compreensão do indivíduo, que apenas pretende fruir seus direitos. De fato, não importa para o indivíduo se a satisfação de seus direitos e de suas necessidades será provida pelo legislador ou pelo julgador ou se este ou aquele tem ou não tem legitimidade para decidir. A questão única que lhe interessa é que há demanda e, ainda que o Estado não a resolva, ela subsistirá como tal, isto é, como situação de fato.

Logo, a sociedade conjugal de fato, estabelecida por casais homossexuais, subsistirá ainda que o Estado persista em negligenciar sua regulamentação, atendendo-se aos princípios que emergem da Constituição. Ou seja, para os casais que assumiram a homossexualidade como opção e estabeleceram o vínculo conjugal entre si, essa escolha e as consequências decorrentes se manterão ainda que o Estado, por qualquer de suas vertentes funcionais, seja omisso e se mantenha nessa condição. E essa postura está diretamente associada, primeiramente, à ampla liberdade de escolha que socorre a todas as pessoas, independentemente da orientação sexual que tenham e, em segundo, porque, nessa mesma condição, todos são dotados da mesma dignidade. Essa perspectiva, queassocia liberdade e dignidade,reflete a própria autonomia individual, considerada como elemento ético da pessoa e representa o "fundamento do livre arbítrio dos indivíduos, que lhes permite buscar, de sua própria maneira, o ideal de viver bem e de ter uma vida boa" (BARROSO, 2014a, p. 81).

Por esse ponto de vista, a opção pela homossexualidade e pelo estabelecimento de união homoafetiva é decisão única que compete exclusivamente ao indivíduo, reservando-se ao Estado a competência para regular, normativamente, os direitos e os deveres decorrentes desse vínculo, abstraindo-se, no mais, de qualquer apego político, religioso, filosófico etc., que possa ser considerado discriminatório.Diante dessa realidade, o único aspecto a ser considerado é que tanto a liberdadequanto a dignidade, enquanto categorias constitucionais que dão suporte aos demais direitos fundamentais, não são suficientemente aptas para romperem a discriminação confessada pelo legislador em detrimento dos interesses dos casais unidos pelo vínculo homoafetivo:

De fato, no plano do valor intrínseco, existe um direito fundamental em favor da legalização do casamento entre pessoas do mesmo sexo: a igualdade perante a lei. Negar o acesso de casais homoafetivos ao casamento - e a todas as consequiências sociais e jurídicas que ele implica - representa uma forma de discriminação baseada em orientação sexual (BARROSO, 2014a, p. 105).

No mais, em sentido contrário à perspectiva discriminatória, tem-se diagnosticado a crescente aceitação da união homoafetiva como mais uma opção pessoal:

Nos últimos anos, a homossexualidade tornou-se um modo de vida cada vez mais aceito e existe uma crença crescente de que as suas causas são predominantemente biológicas. Sendo esse o caso, discriminar alguém somente com base na orientação sexual seria o mesmo que discriminar os asiáticos devido aos seus olhos, os africanos pela sua cor e os latino-americanos pela sua miscigenação étnica (BARROSO, 2014a, p. 104).

Mas causa estranheza o fato de que os representantes eleitos, segundo os critérios estabelecidos pelo regime democrático, tenham adotado postura omissiva diante de questões 
complexas e importantes como a união estável homoafetiva, inexistindo qualquer meio de lhes exigir a supressão de tal omissão ou, ao menos, que a justifiquem. $\mathrm{O}$ reconhecimento jurídico da união estável homoafetiva, então, mostra-se como claro exemplo da distinção entre o que seja o direito e as garantias necessárias à concretização desse direito. $\mathrm{O}$ ativismo não se limita, então, a afirmar que a Constituição prevê o direito à união homoafetiva e a reconhece como tal.

$\mathrm{O}$ cerne do ativismo consiste, em verdade, no desenho dos arranjos normativos e institucionais necessários à fruição dos direitos decorrentes desse reconhecimento, sem que isso aguarde indefinidamente o minudenciamento desses direitos e garantias pelo Parlamento. Assim, diante desse cenário, nada mais democráticodo que possibilitar ao indivíduo a busca de alternativas para a solução de suas demandas junto ao Poder Judiciário.

Atente-se que, nesse caso, ao buscar no Judiciário o deslinde de suas demandas, o indivíduo não cogita quanto a possível ilegitimidade política desse Poder, pois considera que sua satisfação pessoal não se condiciona aos limites da atuação política e muito menos aos regramentos conservadores de ordem social ou religiosa, por exemplo. Basta-lhe, apenas, uma resposta alicerçada numa decisão judicial, ativista ou não. Nesse aspecto, a dignidade, enquanto atributo natural da pessoa humana, primeira se realiza como situação de fato (por exemplo, com o estabelecimento da sociedade conjugal) e, depois, se completa e se consolida com o seu reconhecimento jurídico, pela via legal ou judiciária.

\section{CONCLUSÃO}

Como visto, a realização concreta de alguns importantes direitos de envergadura constitucional somente será possível a partir da compreensão de que foram positivados com a finalidade de atenderem às necessidades humanas e não para servirem de meras promessas, sem qualquer perspectiva de satisfação. Conforme foi demonstrado ao longo desse artigo, embora as competências distribuídas pela Constituição ao Poder Legislativo e ao Poder Judiciário atendam satisfatoriamente à vocação natural de cada um desses Poderes, não se pode olvidar que a finalidade última de suas atuações deve ser dirigida de modo a colocar o ente humano no centro de convergência de suas forças políticas, beneficiando-o, apenas.

Dito isso, pode-se concluir que o principal vetor constitucional, que prima pela dignidade da pessoa humana, associa diretamente o indivíduo, credor da tutela legislativa e jurisdicional, ao Estado de Direito, que se ocupa, por sua vez, de dispor dos meios necessários e suficientespara que as omissões legislativas prejudiciais ao livre exercício desses direitos não se perpetuem, mas sejam prontamente sanadas ante a imediata intervenção da Jurisdição, o que conduz não apenas à satisfação individual até então frustrada, mas à efetividade plena das normas constitucionais.

Diante da realidade que emerge da Constituição, especialmente quanto aos comandos dirigidos ao legislador ordinário, para que edite as leis reputadas necessárias ao implemento de direitos essenciais e da circunstância de que esses comandos não têm sido cumpridos com o rigor imposto pelo legislador constituinte originário, a atuação ativista do Poder Judiciário não apenas se justifica como também se legitima, numa clara relação de causa e efeito, podendo-se em razão disso concluir-se que:i) é descabida a perspectiva de haver sobreposição de um Poder ao outro, uma vez que não se pode imaginar que algo se sobreponha diante do vazio (legislativo), decorrente da omissão reputada inconstitucional, que deve ser, consequentemente, suprimida pela atuação certa e definida do Poder Judiciário, cuja tutela tenha sido provocada pelos titulares dos direitosameaçados; ii) também não é o caso de adjetivar-se a atuação ativista do Judiciário como forma de invasão da competência legislativa, pois verdadeiramente esse não é o caso. O Poder Judiciário ao suprir a omissão legislativa não produz lei propriamente dita, visto que essa competência é exclusiva do Poder Legislativo. Produz, sim, decisão com eficácia erga omnes e 
efeito vinculante, cuja força se assemelha à das leis, mas com elas não se confunde, embora esteja apta a manter-se funcionalmente operante (válida, eficaz e efetiva), enquanto não sobrevier a edição da lei exigida pela Constituição; iii) outro aspecto bastante peculiar quanto à intervenção ativista do Poder Judiciário é que sua decisão, adotada como meio de suprir a omissão legislativa, em nada impede que o Poder Legislativo exerça suascompetências e produza as leis exigidas pela Constituição, preenchendo as lacunas existentes; iv) as decisões ativistas ou não do Poder Judiciário atendemas demandas individuais e coletivas e viabilizam respostas mais eficazes segundo as necessidades dos jurisdicionados, nos casos em que ainda persistam as omissões reputadas inconstitucionais, e v) além disso, essas decisões criam parâmetros para a solução de demandas futuras (precedentes), enquanto persistirem as omissões legislativas.

Tudo isso, analisado em conjunto, revela o lado positivo da atuação ativista judicial, mas há um aspecto negativo que não pode ser olvidado: em razão do mero comodismo do Poder Legislativo, em não assumir o ônus e o risco político de legislar acerca de matérias polêmicas, deixando que estas sejam resolvidas na esfera judicial, pode ocorrer que o Poder Judiciário avance mais incisivamente no campo político, mediante o emprego dos mecanismos de controle de constitucionalidade, tornando-se menos ponderado e menos criterioso em sua contensão (selfrestraint), conduzindo seu ativismo a limites extremos, com a consequente redução da democracia e a institucionalizaçãodo gerenciamento do Estado e da sociedade pela via de um regime aristocrático.

A medida da intervenção ativista do Poder Judiciário na seara da omissão inconstitucional deve ser a que melhor assegure os direitos sociais e individuais, torne efetivos os preceitos constitucionais, preserve o regime democrático e, acima de tudo, mantenha harmônicos os laços que unem os Poderes.

\section{REFERÊNCIAS}

ALEXY, Robert. Constitucionalismo discursivo. Tradução Luís Afonso Heck. Porto Alegre: Livraria do Advogado, 2007.

ARANHA FILHO, Adalberto José Queróz Telles de Camargo; ARANHA, Marina Domingues de Castro Camargo. A legitimidade constitucional do ativismo judicial. Revista de Direito Constitucional e Internacional, São Paulo, v. 86, ano 22, p. 307-325, jan.-mar. 2014.

BARROSO, Luís Roberto. A dignidade da pessoa humana no direito constitucional contemporâneo: a construção de um conceito jurídico à luz da jurisprudência mundial. Belo Horizonte: Fórum, 2014.

Curso de direito constitucional contemporâneo: os conceitos fundamentais e a construção do novo modelo. 5. ed. São Paulo: Saraiva, 2015.

O novo direito constitucional brasileiro: contribuições para a construção teórica e prática da jurisdição constitucional no Brasil. Belo Horizonte: Fórum, 2014.

BOCCATO, Esdras. As deficiências do Poder Legislativo como fator de impulsão do ativismo judicial no Brasil. Revista de Direito Constitucional e Internacional, São Paulo, v. 90, ano 23, p. 63-76, jan./mar. 2015.

BRANCO, Paulo Gustavo Gonet. Juízo de ponderação na jurisdição constitucional. São Paulo: Saraiva, 2009. 
BRANDÃO, Rodrigo. A judicialização da política: teorias, condições e o caso brasileiro. Revista de Direito Administrativo, Rio de Janeiro, v. 263, p. 175-220, maio/ago. 2013.

BRASIL. Congresso Nacional. Veto Total n. 25/2014. Aposto ao Projeto de Lei do Senado n. 104, de 2014 - Complementar (n. 397/2014 - Complementar, na Câmara dos Deputados). Brasília, DF, Diário do Congresso Nacional, ano LXIX, n. 25, 26 nov. 2014. Disponível em: $<$ http://legis.senado.gov.br/diarios/BuscaDiario?datSessao=25/11/2014\&tipDiario=2>. Acesso em: 7 jul. 2016.

Conselho Nacional de Justiça. Provimento n. 37. Dispõe sobre o registro da união estável, no livro "E", por Oficial de Registro Civil das Pessoas Naturais. Brasília, DF, 7 jul. 2014. Disponível em:

<http://www.cnj.jus.br/images/stories/docs_corregedoria/provimentos/provimento_37.pdf>. Acesso em: 7 jul. 2016.

. Conselho Nacional de Justiça. Resolução n. 175. Dispõe sobre a habilitação, celebração de casamento civil, ou de conversão de união estável em casamento, entre pessoas de mesmo sexo. Brasília, DF, 14 maio 2013. Disponível em:

<http://www.cnj.jus.br/images/imprensa/resolu\%C3\%A7\%C3\%A3o_n_175.pdf>. Acesso em: 7 jul. 2016.

.Constituição da República Federativa do Brasil. 45. ed. São Paulo: Saraiva, 2011.

. Lei n. 9.278, de 10 de maio de 1996. Regula o $§ 3^{\circ}$ do art. 226 da Constituição Federal. Diário Oficial [da] República Federativa do Brasil, Brasília, DF, 13 maio 1996. Disponível em: <http://www.planalto.gov.br/CCivil_03/LEIS/L9278.htm>. Acesso em: 7 jul. 2016.

.Novo Código Civil. Brasília: Senado Federal, 2002.

. Presidência da República. Mensagem n. 250. Comunica o veto integral do Projeto de Lei n. 104, de 2014, complementar. Diário Oficial [da] República Federativa do Brasil, Brasília, DF, 27 ago. 2014. Disponível em: <http://www.planalto.gov.br/CCIVIL_03/_Ato20112014/2014/Msg/Vet/VET-250.htm>. Acesso em: 7 jul. 2016.

. Supremo Tribunal Federal. Constitucional. Ação Direta de Inconstitucionalidade n. 4.277/DF, Brasília, DF, 14 out. 2011. Disponível em: <http://redir.stf.jus.br/paginadorpub/paginador.jsp?docTP=AC\&docID=628635>. Acesso em: 7 jul. 2016.

Supremo Tribunal Federal. Constitucional. Ação Direta de Inconstitucionalidade n. 3.276-3 CE, Brasília, DF, 2 jun. 2005. Disponível em: <http://redir.stf.jus.br/paginadorpub/paginador.jsp?docTP=AC\&docID=506567>. Acesso em: 7 jul. 2016.

Supremo Tribunal Federal. Constitucional. Mandado de Injunção n. 795-1 DF, Brasília, DF, 25 out. 2007. Disponível em: <http://redir.stf.jus.br/paginadorpub/paginador.jsp?docTP=AC\&docID=593668>. Acesso em: 7 jul. 2016.

Supremo Tribunal Federal. Constitucional. Mandado de Injunção n. 712-8 PA, Brasília, DF, 15 abr. 2009. Disponível em: 
<http://redir.stf.jus.br/paginadorpub/paginador.jsp?docTP=AC\&docID=558553>. Acesso em: 7 jul. 2016.

Supremo Tribunal Federal. Constitucional. Mandado de Injunção n. 943 DF, Brasília, DF, 6 fev. 2013. Disponível em: <http://redir.stf.jus.br/paginadorpub/paginador.jsp?docTP=TP\&docID=3716117>. Acesso em: 7 jul. 2016.

Supremo Tribunal Federal. Constitucional. Súmula Vinculante n. 33, Brasília, DF, 9 abr. 2014. Disponível em:

<http://www.stf.jus.br/portal/jurisprudencia/listarJurisprudencia.asp?s1=33.NUME.\%20E\%20S.F LSV.\&base=baseSumulasVinculantes>. Acesso em: 7 jul. 2016.

CARVALHO, Ernani Rodrigues de. Em busca da judicialização da política no Brasil: apontamentos para uma nova abordagem. Revista de Sociologia e Política, Curitiba, n. 23, p. 115-126, nov. 2004.

DIAS, Maria Berenice. Manual de direito das famílias. 9. ed. São Paulo: Editora Revista dos Tribunais, 2013.

ELY, John Hart. Democracia e desconfiança: uma teoria do controle judicial de constitucionalidade. Tradução Juliana Lemos. São Paulo: Martins Fontes, 2010.

KELSEN, Hans. Jurisdição constitucional. Tradução Alexandre Krug. São Paulo: Martins Fontes, 2007.

MENDES, Gilmar Ferreira. Direitos fundamentais e controle de constitucionalidade: estudos de direito constitucional. São Paulo: Instituto Brasileiro de Direito Constitucional, 1998.

Saraiva, 2012.

; BRANCO, Paulo Gustavo Gonet. Curso de direito constitucional. 7. ed. São Paulo:

MORO, Sérgio Fernando. Desenvolvimento e efetivação judicial das normas constitucionais. São Paulo: Editora Max Limonad, s.d.

RAWLS, John. Justiça e democracia. Tradução Irene A. Paternot. São Paulo: Martins Fontes, 2000.

SCHMITT, Carl. O guardião da constituição. Tradução Luiz Moreira. Belo Horizonte: Del Rey, 2007.

SHERRY, Suzanna. Why we need more judicial activism. Vanderbilt University - Law School, Nashville, TN, p. 1-21, feb. 2013. Disponível em: <http://ssrn.com/abstract=2213372>. Acesso em: 7 jul. 2016.

TEIXEIRA, Anderson Vichinkeski. Ativismo judicial: nos limites entre racionalidade jurídica e decisão política. Revista Direito GV, São Paulo, v. I, p. 37-53, jan./jun. 2012.

VALLE, Vanice Regina Lírio do (Org.). Ativismo jurisdicional e o Supremo Tribunal

Federal. Curitiba: Juruá, 2009. 